\title{
Gesture-based Technology and Organisational Strategy: A Study of a Quick Service Restaurant Franchisor
}

\author{
Nishal Ragobeer \\ Rembrandt Klopper \\ Sam Lubbe
}

\begin{abstract}
The aim of the study was to derive a theoretical framework that is hinged on critical success factors, enablers and Inhibitors, for the Alignment of GestureBased Technology and Organisational Strategy for the quick serving restaurant sector. The critical success factors, enablers and inhibitors that were used to formulate the framework were extrapolated from the literature. The sample design of this research study is a Non-Random, Purposive Sample. The key analysis of the research was to test whether critical success factors, enablers and inhibitors indeed can be used to derive a theoretical framework using a questionnaire. It was concluded that critical success factors, enablers and inhibitors were indeed core to the formulation of a theoretical framework. All of the critical success factors, enablers and inhibitors presented in the sample were accepted.
\end{abstract}

Keywords: Theoretical framework, gesture-based technology, organizational strategy, alignment, critical success factors, enablers, inhibitors

\section{Introduction}

This paper focused on deriving a framework for the alignment of Gesture Based Technology (GBT), specifically tablets and touch screen devices (mobile smart phones), with organisational strategy. To undertake this research 
the organisation Yum! Restaurants International was used based on the prevalence of this technology within the organisation. The literature used was scholarly journal articles, and text books published $2004-2011$.

\section{Literature Review}

Over the years there has been an infiltration of new technologies that redefined business and the manner in which business is undertaken. This is affirmed by likes of Lubbe (2005), Tarafdar and Qrunfleh (2010), and Chan and Reich (2007). Like the Internet, the social networking paradigm, mobile computing, and of recent GBT has once again radically redefined the manner in which business is undertaken (Johnson et al. 2010).

Musuka (2006), Lubbe (2005), Lubbe and Pather (2003), Tarafdar and Qrunfleh (2010) all researched the problem of aligning IT and business strategy. The common theme that permeates through the research on the Internet and business strategy alignment is that competitive advantage and success aligned with real threats around inefficient business processes and market penetration.

Yum! is a restaurant company with more than thirty-six thousand restaurants in the world and a presence in more than one hundred and ten countries. Yum! has three key companies Yum!, Yum! Restaurants International (YRI) and Yum! China. The company has three key brands in its stable and these encompass Taco Bell, Pizza Hut and Kentucky Fried Chicken (KFC) (Blanchard et al. 2004). The systems at a store (e.g. KFC) level predominantly entail touch screen point of sale systems that evolves into next generation services systems.

GBT architecture incorporates wireless technology as its principle and primary network connectivity model to transfer and relay information around gestures (Roth 2000). Smart-phones, Tablets and even Sixth Sense technology (Mistry, Maes \& Chang 2009) adopt wireless technology for network connectivity (Johnson, Levine, Smith \& Stone 2010). Motion detection (GBT) devices like Sony's, Microsoft's Kinect and also Nintendo's Wii (Shah \& Haigh 2005) all require wireless connectivity to connect controllers to the control unit.

\section{Gesture Based Technology}

Traditionally and the keyboard and mouse are the primary and most renowned 
ways to interact with and input data into a computer. In the last decade a greater emphasis has been placed on innovative ways of computer input for example direct input via touch screen devices, tangible user interfaces and recently GBT (Wu \& Luo 2006). Mobile Devices (Smart Phones and Tablets) and Touch Screen Computers solve for gesture based interaction by exploitation of screen input through finger touches, swipes and taps (Wilson 2004; 2010; Lee 2010). Sixth Sense (Mistry et al. 2009) technology is an example of a combination of input and interaction methods.

\section{Organisational Strategy and IT Alignment}

Alignment of IT/IS with organisational strategy has been researched since the conflation of technology into the business landscape. Strategy can be defined as the long-term plan to achieving business objectives taking various environmental factors into account. Gregor, Hart and Martin (2007), and Bush, Lederer, Li, Palmisanno and Rao (2009), define alignment as the degree to which the IT mission, objectives, and plans support and are supported by the business mission, objectives and plans.

A critical success factor for Wireless Grids is the willingness for consumers to share resources and the technology is significantly reliant on the notion of sharing (Roussos \& Kostakos 2009). Closely linked to wireless grids are Radio Frequency Identity (RFID) chips. These chips need to be small, less intrusive and robust and need to have alternate power sources that are long lasting (Roussos \& Kostakos 2009). When researching touch pens a critical success factor that stood out was its size and accuracy to capture the users actions that is writings (Wu \& Luo 2006) For Brain Computer Interfaces (GBT foundation) the critical success factor would be the ability to interpret and understand human thoughts (Nijholt, Plass-Oude \& Reuderink 2009; Wobbrock et al. 2008).

Chang and Yang (2008), Huang and Hu (2007), and Tallon (2008) argue that the sharing of business strategy, goals and objectives with the IT team and its leaders is a key enabler. Chen (2010), Huang and $\mathrm{Hu}$ (2007), Musuka (2006), and Tallon (2008) also assert that, and that the advantage of alignment is that you will have business and IT strategy that complement each other, and create harmony between business and IT. Another advantage is that alignment will ensure that IT and business leaders can converse and engage in terms of similar understanding of their businesses. 


\section{Research Methodology}

A summary of the research problem stated as questions was: What are the Critical Success Factors (CSF's), An identification of Enablers and Inhibitors that would drive that alignment of GBT (touch screen, smart phone and tablet technology) and organisational strategy to ensure competitive advantage and enhanced business performance is not easy.

Germinating out of the research problem are research questions.

1. What are critical success factors for the alignment of GBT (touch screen, smart phone and tablet technology ) and organisational strategy;

2. What are the enablers for the alignment of GBT (touch screen, smart phone and tablet technology) and organisational strategy; and,

3. What are the inhibitors to the alignment of GBT touch screen, smart phone and tablet technology) and organisational strategy

The research method chosen for this study is a quantitative research design type. By using the various numerical and statistical tools and methods, various permutations and responses were formulated that could help answer the research questions. The primary data were collected through a questionnaire that was circulated to the sample using Surveymonkey.

The questionnaire was superseded with a covering letter outlining the confidentiality of the data and also the ability of a respondent to answer questions anonymously. The population encompassed a total of approximately five hundred employees. Yum! Restaurants International and its African subsidiary together with two other companies and Yum! make up the multinational company Yum!. The Sample adopted for this research study is a Non-Random, sampling design. A sample size of one hundred and four (104) has been surveyed.

\section{Research Findings}

The age groups of respondents were between thirty-five and forty-nine years $(56.1 \%)$, followed by between twenty-five and thirty-four years $(36.6 \%)$. Therefore it is evident that a consistent cross section of the sample across age 
groups was present. There are always differences in the views and opinions of females and males (Wijngaert \& Bouwman 2009). The numbers infer that Yum! Restaurants International (YRI) employs more males than females. The sample breakdown was considered to be a fair representation of the demographics at YRI restaurants with respect to GBT and Organisational Strategy Alignment (53.7\% males).

The years of employment by employees within an organisation is crucial to it sustenance, growth and maturity (Chen 2010). The tenure group was greater than five $(>5)$ years $(39 \%)$ followed by zero to one $(0-1)$ years $(18.3 \%)$. The research revealed that the majority of the respondents were working at YRI for more than five years.

The job ranking within Yum! was Managerial (68.3\%), followed by Non-managerial (25.6\%). The sample is dominated by respondents who were in the managerial ranking and this is pivotal in deriving a deep understanding the impact of GBT and Organisational Strategy Alignment enablers, success factors and inhibitors (Musuka 2006). Furthermore a holistic picture can be achieved since the input of Non-managerial respondents $(25.6 \%)$ and Administrative staff was invaluable in identifying these success factors, enablers and inhibitors. The role played by respondents in the development of organisational and technology strategy, was a moderate role $(43.9 \%)$ followed closely by the key role $(42.7 \%)$. An almost even distribution of respondents who feel that they play a key role and those who play a moderate role in the development of strategy.

\section{Understanding and Knowledge of Gesture Based Technology, and of Technology and Organisational Strategy Alignment} Having a sample would the correct knowledge and wisdom around the topic being researched lends itself to deriving a research study with a high accuracy and reliability (Leedy \& Omrod 2005).

The knowledge level of GBT was 'I am a novice' (39.5\%) followed by 'I have expert knowledge' (27.2\%). It must be noted that almost $40 \%$ of the sample have novice knowledge of GBT, $27.2 \%$ of the respondents have expert knowledge. Furthermore $12.3 \%$ of the sample has no knowledge of GBT. The research confirms the fact that GBT is essential for the progress and the achieving of goals within YRI since $96.3 \%$ of the respondents in the sample reveal that they own at least one device. The response to this question was 'I 
have not been involved' in the roll out of any tablet, touch screen smart phone, or any touch screen device in the organisation.

\section{Know and Understand Your Organisational Strategy}

The response was 'I have expert knowledge' (33.3\%) followed by 'I am a novice' (29.6\%) when it comes to knowledge of the organisational strategy. The research reveals that collectively $90.1 \%$ of the sample considered the GBT (tablets, touch screen smart phone or any touch screen device) and the business strategy to be aligned as important to significantly important. This reiterates the fact that in order for any organisation to be productive it is imperative that the GBT and the business strategy be aligned.

\section{Critical Success Factors, Enablers and Inhibitors of GBT and Organisational Strategy Alignment}

The critical success factors presented to the sample were derived from the research undertaken by Roth (2000). The three Critical Success Factors of GBT was: 1) Having a Wireless Network in place (17.7\%); 2) Cost of GBT (16.4\%); and 3) Accuracy in capturing gestures (finger taps, finger swipes and finger pointing) (15.1\%) and Various value added services offered by the GBT $(15.1 \%)$. From the above the critical success factors can be derived in relation to the respondents' preference and immediately the Critical Success Factors are identified.

The enablers presented to the sample were hinged on the research undertaken by Wijngaert and Bouwman (2009). The analysis finds the following three enablers for GBT: 1) Demand for ubiquitous (anywhere/anytime) computing/technology $(21.2 \%) ; 2$ ) Accessibility of GBT (17.6\%); and 3) Lower costs of GBT (15\%). The three inhibitors for GBT were: 1) Total cost of ownership for deploying GBT $(31.5 \%)$; 2) GBT computers capabilities (processor power; memory and storage capacity) (15.2\%); and 3) Limited features of GBT $(11.5 \%)$. The inhibitors used in this research study were adopted from the research undertaken by Roussos and Kostakos (2009).

All the critical success factors extrapolated from the literature review have been identified and selected by the sample as critical success factors for strategy alignment. Chan and Reich (2007), Chen (2010), Tarafdar and 
Qrunfleh (2009), and Roussos and Kostakos's (2009) research formed the basis for the critical success factors presented to the sample.

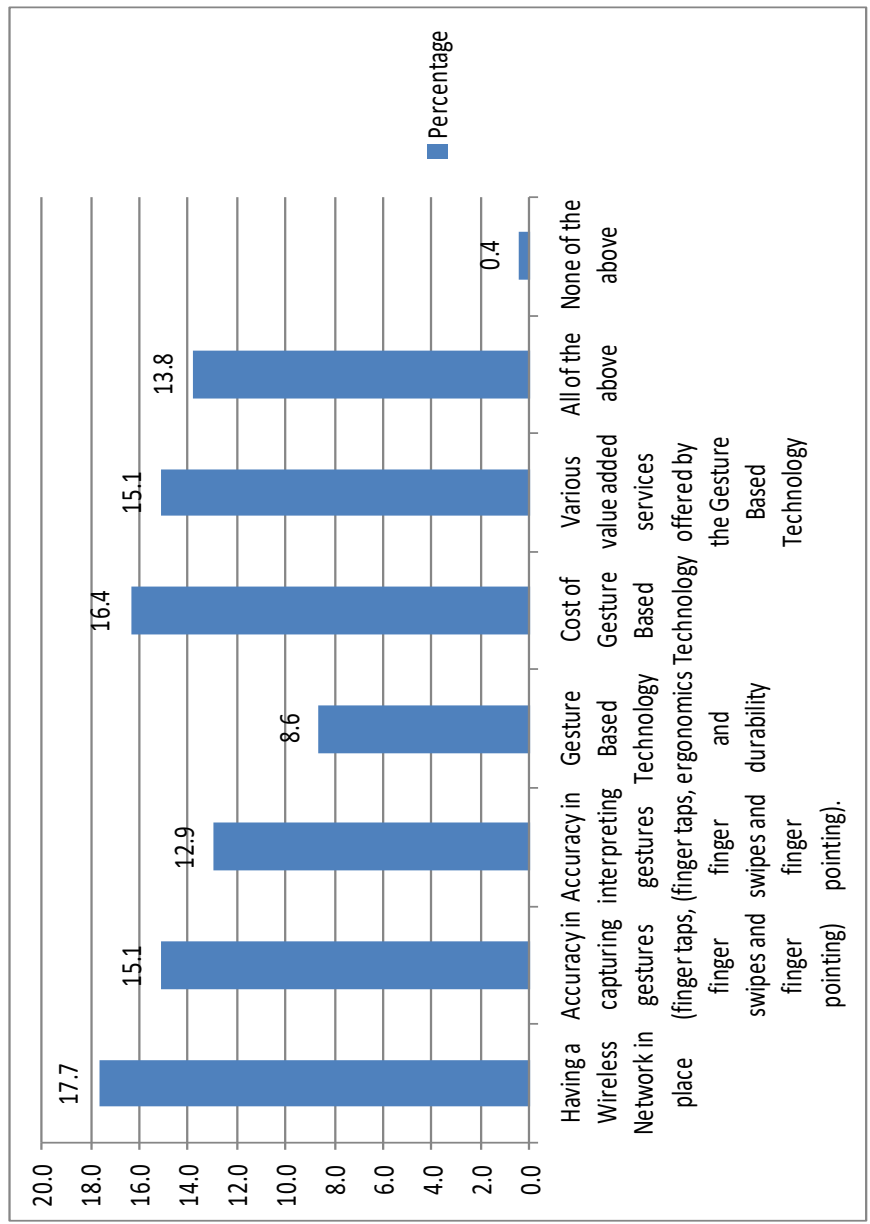

Figure 1: Critical Success Factors of Gesture-Based Technology

The five enablers for strategy alignment identified encompass: 1) Sharing the business strategy with IT; 2) Having complimentary IT and Organisational strategies; 3) Having enterprise architecture for GBT; 4) Criticality of sharing information and knowledge across multiple platforms to 
Nishal Ragobeer, Rembrandt Klopper \& Sam Lubbe

the business; and 5) Lower costs of GBT. The sample selected them all.

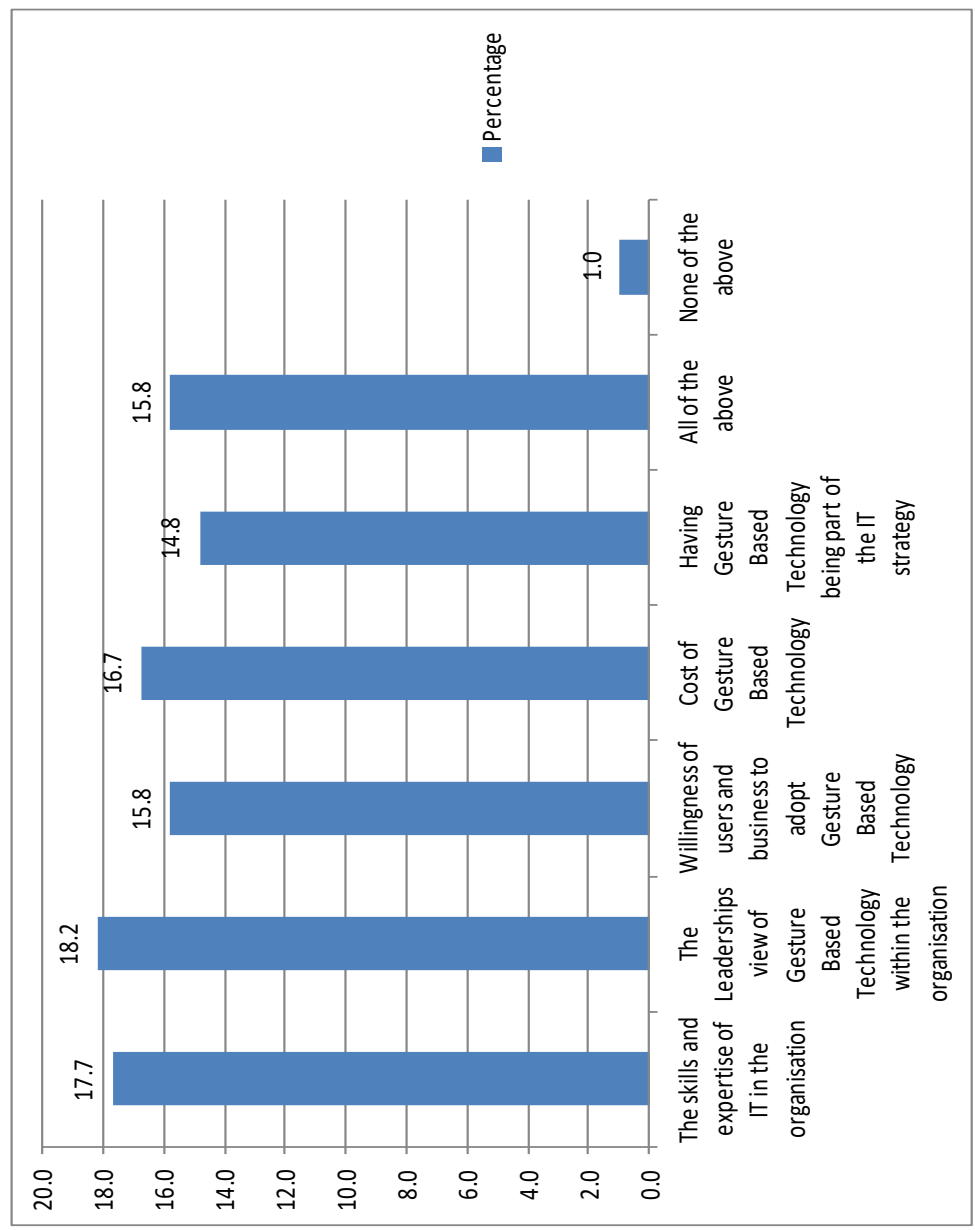

\section{Figure 2: Critical Success Factors of Strategy Alignment}

The five Inhibitors for Strategy Alignment presented to the sample encompassed: 1) IT now knowing the business strategy; 2) No organisational strategy for the use of GBT; 3) Traditional role of IT in the business; 4) Readiness of business environment for GBT; and 5) IT not driving innovation in the 
business. The inhibitors are embedded in the research undertaken by Chan and Reich (2007); Chen (2010); and Musuka (2006). The sample supported the five Inhibitors presented to them. From the research undertaken by Wijngaert and Bouwman (2009), Musuka (2006) it is evident that having a balanced approach in relation to demographics steers insightful research is important.

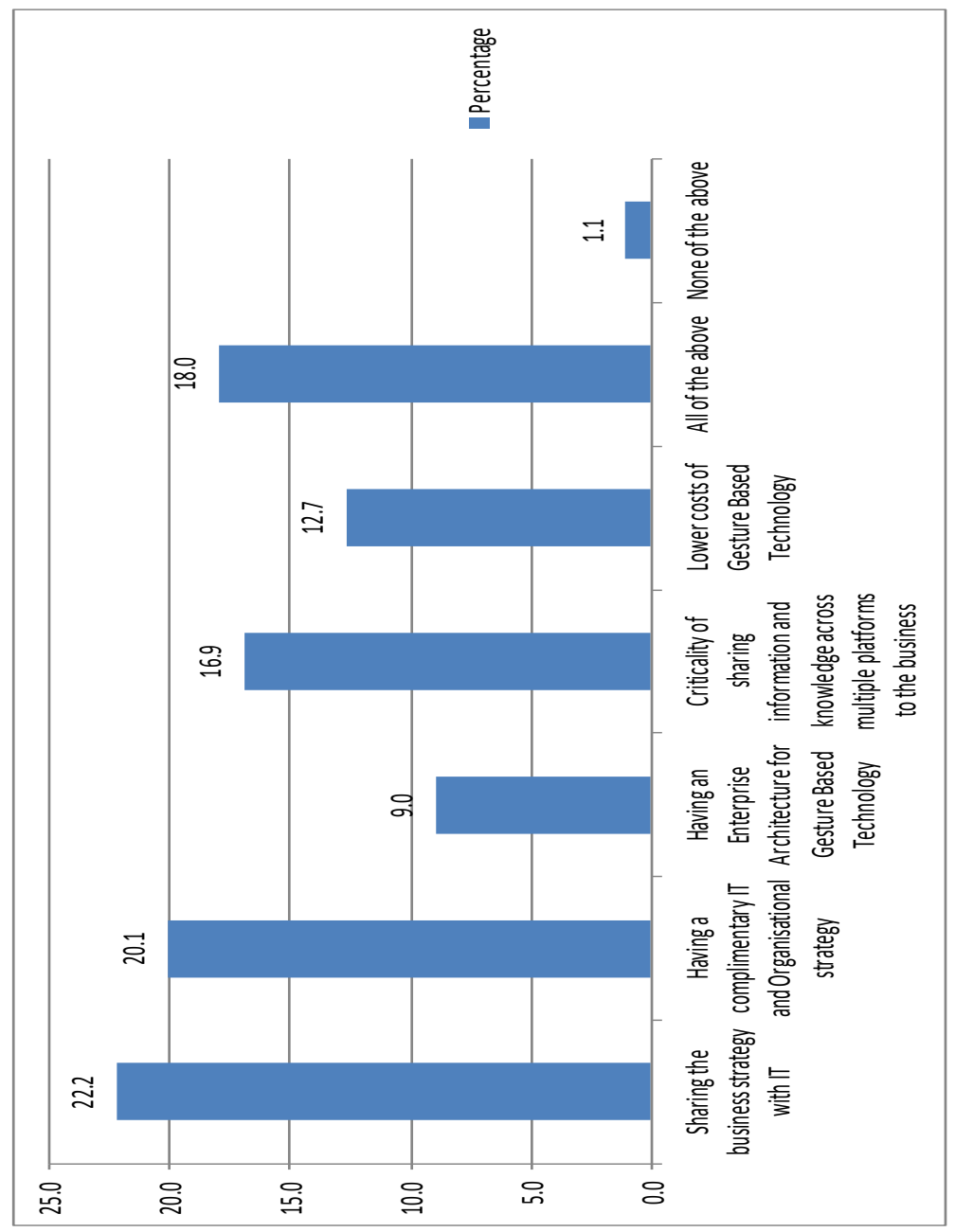

Figure 3: Enablers of Strategy Alignment 


\section{Understanding and Knowledge of Gesture Based Technology and Organisational Strategy Alignment}

Wijngaert and Bouwman (2009) state that the readiness of an environment and the knowledge within the organisation of the technology lead to its successful adoption and use. Thirty nine point five percent of the respondents felt that they are novices regarding their knowledge of GBT whilst $27.2 \%$ of the respondents felt that they had expert knowledge. The researchers find that regarding the usage of GBT, the respondents classified themselves as a competent user (48.1\%) and a somewhat competent user (34.6\%) whilst $46.9 \%$ of the respondents own 2 or more GBT devices and there was an even split of those who owned (2) devices $24.7 \%$. The research reveals that when it comes to the rollout of any tablet, touch screen smart phone or any touch screen device solution in the organisation, respondents have not been involved $(67.9 \%)$ and or haven been moderately involved (21\%).

\section{Enablers and Inhibitors of Gesture Based Technology and Gesture Based Technology and Organisational Strategy Alignment}

The objective of presenting these extrapolations to the sample is to gain confirmation of its validity.

\section{Descriptive Statistics}

In this section the mean, the mode, the median, the sample variance and the sample standard deviation are discussed. The majority of the questions have modes of ' 2 ' and ' 3 ' and these can be translated in accordance with the responses from the scales of the relevant question. The standard deviations were consistently about ' 1 ' and this indicates good consistency between the observations due to the low variability. The mean and median values are consistent with modal values.

\section{Reliability Analysis}

The Cronbach's Alpha was calculated as part of reliability and validity analysis. A value of 0.7 or higher was deemed to conclude a good internal 
consistency and reliability amongst the questions. The Cronbach's alpha can range from zero (0) to one (1).Cronbach's alpha was also calculated as part of the reliability test to assess how consistent the results were and to determine if similar results will be obtained to generalize if the sample size was increased. A value of zero point seven (0.7) or higher was a good value that enabled the researchers to state that the results would stay the same if the survey was carried out with a larger sample of respondents. The Cronbach's alpha was calculated for all the questions that have the same scales in each section.

\section{Kolmogorov Smirnov Test}

The Kolmogorov-Smirnov tested whether the sample responses follow a normal distribution and whether or not parametric or non-parametric techniques can then be used on the sample responses. The two hypotheses formulated are as follows:

H0: the tested variables come from a Normal distribution

H1: the tested variables do not come from a Normal distribution

At the 5\% significance level, $\mathrm{H} 0$ has to be rejected for the questions of which p-values are less than 0.05 and conclude that the tested variables do not come from a Normal distribution. In this case since the p-values are all less than zero point zero five $0.05, \mathrm{H} 0$ is reject and the conclusion is that further analysis is required on these questions using non-parametric tests.

\section{Testing of the Objectives}

In order to test the objectives, the Chi-Square goodness of fit test was used. Leedy and Omrod (2010) state that there are two main types of chi-square test. The results from the test are summarized below:

H0: The use of the enablers, inhibitors and success factors are not necessary to develop a founding theory for GBT and organisational strategy alignment. 
H1: The use of the enablers, inhibitors and success factors are necessary to develop a founding theory for GBT and organisational strategy alignment.

\section{Test Statistics}

At the $5 \%$ significance level the p-values are less than 0.05 , therefore $\mathrm{HO}$ is rejected. The conclusion is that the use of critical success factors, enablers and inhibitors are necessary to develop a theory for GBT and organisational strategy alignment.

Testing for Relationships between the Demographics and the Understanding and Knowledge of Gesture Based Technology

\begin{tabular}{|l|l|l|}
\hline Question & Chi-square test statistic & P-value \\
\hline 3.1 & 16.608 & 0.411 \\
\hline 3.2 & 12.179 & 0.732 \\
\hline 3.3 & 30.855 & 0.002 \\
\hline 3.4 & 13.597 & 0.093 \\
\hline 3.5 & 21.724 & 0.152 \\
\hline 3.6 & 17.192 & 0.143 \\
\hline 3.7 & 7.690 & 0.262 \\
\hline 3.8 & 90.881 & 0.000 \\
\hline
\end{tabular}

Table 1: Chi-Square Test of Independence - Relationship between age and knowledge of gesture based technology

At the 5\% significance level the conclusion is that there is a relationship between age and question 3.3 and question 3.8. Question 3.3. Do you currently own a GBT device in the form of a tablet, touch screen smart phone or any touch screen device? Question 3.8. How important is it to have GBT (tablets, touch screen smart phone or any touch screen device) and the business strategy aligned? However, for the rest of the questions since the pvalues are greater than 0.05 , the conclusion is that there are no relationships between age, the understanding and knowledge of GBT. 
Gesture-based Technology and Organisational Strategy

\begin{tabular}{|l|l|l|}
\hline Question & Chi-square test statistic & P-value \\
\hline 3.1 & 13.292 & 0.010 \\
\hline 3.2 & 9.515 & 0.049 \\
\hline 3.3 & 21.309 & 0.000 \\
\hline 3.4 & 15.542 & 0.000 \\
\hline 3.5 & 15.599 & 0.004 \\
\hline 3.6 & 9.475 & 0.024 \\
\hline 3.7 & 1.884 & 0.390 \\
\hline 3.8 & 4.723 & 0.193 \\
\hline
\end{tabular}

\section{Table 2: Chi-Square Test of Independence - Relationship between gender and knowledge of GBT}

At the 5\% significance level the conclusion is that there is a relationship between gender and all of the questions since their p-values are less than zero point zero five (0.05). Question 3.1. Do you have knowledge of GBT (GBT)? Question 3.2. Do you currently use a GBT device in the form of a tablet, touch screen smart phone or any touch screen device? Question 3.4. Have you been involved in the rollout of any tablet, touch screen smart phone or any touch screen device/solution in your organisation? Question 3.5. Do you know and understand the organisational strategy? Question 3.6. Do you think it is important to have technology and business strategy alignment?

\begin{tabular}{|l|l|l|}
\hline Question & Chi-square test statistic & P-value \\
\hline 3.1 & 15.874 & 0.462 \\
\hline 3.2 & 23.222 & 0.108 \\
\hline 3.3 & 16.807 & 0.157 \\
\hline 3.4 & 4.512 & 0.808 \\
\hline 3.5 & 21.135 & 0.173 \\
\hline 3.6 & 11.876 & 0.456 \\
\hline 3.7 & 3.746 & 0.879 \\
\hline 3.8 & 19.280 & 0.082 \\
\hline
\end{tabular}

Table 3: Chi-Square Test of Independence - Relationship between tenure and knowledge of gesture based technology. 
At the 5\% significance level the conclusion is that there are no relationships tenure and understanding and knowledge of GBT since all the pvalues are greater than 0.05 . The relationships between the rankings within Yum! and YRI, and understanding and knowledge of GBT using the ChiSquare test of independence, was tested.

At the 5\% significance level the conclusion is that there are relationships between rankings within Yum! and YRI, and question 3.2, 3.3, 3.5 and 3.6 since the p-values for these questions are less than 0.05 . The chisquare test for independence was also used to test for a relationship between developmental role and understanding and knowledge of gesture based technology.

\begin{tabular}{|l|l|l|}
\hline Question & Chi-square test statistic & P-value \\
\hline 3.1 & 14.531 & 0.069 \\
\hline 3.2 & 21.442 & 0.006 \\
\hline 3.3 & 21.634 & 0.001 \\
\hline 3.4 & 18.263 & 0.001 \\
\hline 3.5 & 32.081 & 0.000 \\
\hline 3.6 & 23.864 & 0.001 \\
\hline 3.7 & 6.028 & 0.197 \\
\hline 3.8 & 11.757 & 0.068 \\
\hline
\end{tabular}

Table 4: Chi-Square Test of Independence - Relationship between a role in developing organisational strategy and GBT, and knowledge of GBT

At the 5\% significance level the conclusion is that there are relationships between developmental role and questions 3.2, 3.3, 3.4, 3.5 and 3.6 since the $\mathrm{p}$-values for these questions are less than 0.05 .

\section{Relating the Demographic Variables to Critical Success Factors, Enablers and Inhibitors of GBT and Strategy Alignment}

The assessment of the demographic variables in relation to the critical success factors, enablers and inhibitors will lead to a significantly reliable and valid research study. Some of the key literary studies, Leedy and Omrod (2005), 
Musuka (2006) place emphasis on correlating the demographic variables with the core of the research study. In so doing they argue there will be significant better insights and answers into the research question.

As is evidenced by the analysis and table above, the critical success factors are the same across all of the age groups. Within this section it is established that the critical success factors extrapolated are consistent across the age groups. This confirms a level of reliability and validity with the analysis and findings.

\begin{tabular}{|c|c|c|c|c|c|c|c|c|}
\hline Age & $\begin{array}{c}\text { Demand for } \\
\text { ubiquitous } \\
\text { (anywhere/a } \\
\text { nytime) } \\
\text { computing / } \\
\text { technology }\end{array}$ & $\begin{array}{c}\text { Cloud } \\
\text { computing } \\
\text { technology }\end{array}$ & $\begin{array}{c}\text { Lower costs } \\
\text { of Gesture } \\
\text { Based } \\
\text { Technology }\end{array}$ & $\begin{array}{c}\text { Accessibility } \\
\text { of Gesture } \\
\text { Based } \\
\text { Technology }\end{array}$ & $\begin{array}{c}\text { Size and } \\
\text { robustness } \\
\text { of Gesture } \\
\text { Based } \\
\text { Technology }\end{array}$ & $\begin{array}{c}\text { Having a } \\
\text { library of } \\
\text { gestures } \\
\text { (finger taps, } \\
\text { finger } \\
\text { swipes, etc) }\end{array}$ & $\begin{array}{c}\text { All of the } \\
\text { above }\end{array}$ & $\begin{array}{c}\text { None of } \\
\text { the above }\end{array}$ \\
\hline $18-24 \mathrm{yrs}$ & 18 & 12 & 8 & 12 & 14 & 4 & 8 & \\
\hline $25-34 \mathrm{yrs}$ & 18 & 16 & 21 & 21 & 13 & 3 & 15 & \\
\hline $35-49 \mathrm{yrs}$ & 21 & & & 1 & & 1 & 2 & \\
\hline $50-60 \mathrm{yrs}$ & 2 & & & & & & & 1 \\
\hline
\end{tabular}

\section{Table 5: Relationship between Age and Enablers of Gesture Based Technology}

The analysis of the table above indicates a consistency of across all the ages in relation to the enablers. Only one respondent within the age group of eighteen to twenty four years did not believe that any of the enablers were applicable. These enablers are in line with literary review undertaken. It is evident the extrapolated enablers are consistent across the age groups. This confirms a significant level of reliability and validity with the analysis and findings.

The analysis of table 6 indicates a consistency across all the ages in relation to the inhibitors. These inhibitors are in line with literary review undertaken. The extrapolated inhibitors are consistent across the age groups. This confirms reliability and validity with the analysis and findings. 
Nishal Ragobeer, Rembrandt Klopper \& Sam Lubbe

\begin{tabular}{|l|c|c|c|c|c|c|c|c|}
\hline Age & $\begin{array}{c}\text { Total cost of } \\
\text { ownership } \\
\text { for deploying } \\
\text { Gesture } \\
\text { Based } \\
\text { Technology }\end{array}$ & $\begin{array}{c}\text { Limited } \\
\text { features of } \\
\text { Gesture } \\
\text { Based } \\
\text { Technology }\end{array}$ & $\begin{array}{c}\text { Stability of } \\
\text { Gesture } \\
\text { Based } \\
\text { Technology }\end{array}$ & $\begin{array}{c}\text { Screen } \\
\text { size and } \\
\text { ease of } \\
\text { use }\end{array}$ & $\begin{array}{c}\text { Gesture } \\
\text { Based } \\
\text { Technology } \\
\text { computers } \\
\text { capabilities } \\
\text { (processor } \\
\text { power; } \\
\text { memory and } \\
\text { storage } \\
\text { capacity) }\end{array}$ & $\begin{array}{c}\text { Understanding } \\
\text { a multitude of } \\
\text { gestures at } \\
\text { once }\end{array}$ & $\begin{array}{c}\text { All of the } \\
\text { above }\end{array}$ & $\begin{array}{c}\text { None of } \\
\text { the above }\end{array}$ \\
\hline $18-24 \mathrm{yrs}$ & & & & & & & & \\
\hline $25-34 \mathrm{yrs}$ & 21 & 7 & 9 & 6 & 8 & 7 & 4 & 1 \\
\hline $35-49 \mathrm{yrs}$ & 27 & 10 & 9 & 11 & 17 & 10 & 9 & 1 \\
\hline $50-60 \mathrm{yrs}$ & 4 & 2 & & 1 & & & & 1 \\
\hline
\end{tabular}

\section{Table 6: Relationship between Age and Inhibitors of Gesture Based} Technology

As is evidenced by the analysis, the critical success factors are the same across all of the age groups. The sample all agree with the critical success factors extrapolated. Within this section it is established that the critical success factors extrapolated are consistent across the age groups. This confirms a significant level of reliability and validity with the analysis and findings.

\begin{tabular}{|c|c|c|c|c|c|c|c|}
\hline Age & $\begin{array}{c}\text { Sharing the } \\
\text { business } \\
\text { strategy } \\
\text { with IT }\end{array}$ & $\begin{array}{c}\text { Having a } \\
\text { complimentary IT } \\
\text { and } \\
\text { Organisational } \\
\text { strategy }\end{array}$ & $\begin{array}{c}\text { Having an } \\
\text { Enterprise } \\
\text { Architecture } \\
\text { for Gesture } \\
\text { Based } \\
\text { Technology }\end{array}$ & $\begin{array}{c}\text { Criticality of } \\
\text { sharing } \\
\text { information } \\
\text { and } \\
\text { knowledge } \\
\text { across } \\
\text { multiple } \\
\text { platforms to } \\
\text { the business }\end{array}$ & $\begin{array}{c}\text { Lower costs of } \\
\text { Gesture Based } \\
\text { Technology }\end{array}$ & $\begin{array}{c}\text { All of } \\
\text { the } \\
\text { above }\end{array}$ & $\begin{array}{c}\text { None } \\
\text { of the } \\
\text { above }\end{array}$ \\
\hline $18-24 \mathrm{yrs}$ & & & & & & & \\
\hline $25-34 \mathrm{yrs}$ & 13 & 8 & 5 & 11 & 6 & 14 & 1 \\
\hline $35-49 \mathrm{yrs}$ & 26 & 27 & 10 & 19 & 15 & 19 & \\
\hline $50-60 \mathrm{yrs}$ & 3 & 3 & 2 & 2 & 3 & 1 & \\
\hline
\end{tabular}

Table 7: Relationship between Age and Enablers of Strategy Alignment 
The enablers extrapolated from the research undertaken by Bush, Lederer, Li, Palmisanno and Rao (2009) encompass: 1) Sharing business strategy with IT; 2) Having complementary IT and Organisational strategy; 3) Having and enterprise architecture for GBT; 4) Criticality of sharing information and knowledge across multiple platforms to the business; and 5) Lower costs of GBT. The sample selected all of the enablers presented to them. The table indicates that the enablers extrapolated are consistent across the age groups.

It is that the age groups twenty five to thirty four, thirty five to forty nine and fifty to sixty years are age groups with the greatest representation across the inhibitors. It is therefore deduced that the inhibitors are evenly distributed across the above three age groups. It is also deduced that the respondents are predominantly within the ages of twenty five to fifty years. This once again confirms the diversity and wealth of knowledge available on new technologies. Wijngaert and Bouwman (2009), and Musuka (2006) all related the importance of having a representative sample within the appropriate age bands.

\begin{tabular}{|c|c|c|c|c|c|c|c|c|}
\hline Gender & $\begin{array}{l}\text { Having a } \\
\text { Wireless } \\
\text { Network } \\
\text { in place }\end{array}$ & $\begin{array}{c}\text { Accuracy in } \\
\text { capturing } \\
\text { gestures } \\
\text { (finger taps, } \\
\text { finger swipes } \\
\text { and finger } \\
\text { pointing) }\end{array}$ & $\begin{array}{l}\text { Accuracy in } \\
\text { interpreting } \\
\text { gestures } \\
\text { (finger taps, } \\
\text { finger swipes } \\
\text { and finger } \\
\text { pointing). }\end{array}$ & $\begin{array}{c}\text { Gesture } \\
\text { Based } \\
\text { Technology } \\
\text { ergonomics } \\
\text { and } \\
\text { durability }\end{array}$ & \begin{tabular}{|c|} 
Cost of \\
Gesture \\
Based \\
Technology
\end{tabular} & $\begin{array}{c}\text { Various } \\
\text { value added } \\
\text { services } \\
\text { offered by } \\
\text { the Gesture } \\
\text { Based } \\
\text { Technology }\end{array}$ & $\begin{array}{c}\text { All of the } \\
\text { above }\end{array}$ & $\begin{array}{c}\text { None of } \\
\text { the } \\
\text { above }\end{array}$ \\
\hline Males & 23 & 23 & 18 & 11 & 26 & 17 & 15 & \\
\hline Females & 18 & 12 & 12 & 9 & 12 & 18 & 17 & 1 \\
\hline
\end{tabular}

\section{Table 8: Relationship between Gender and Critical Success Factors of GBT}

The criticality of correlating gender to the critical success factors is to establish if any significant differences exist between males and females in relation to critical success factors chosen (Wijngaert \& Bouwman 2009; Cheng and Wang 2010). It is generally accepted that males and females do have differing tastes, preferences and choices (Leedy \& Omrod 2005). As is 
evidenced both males and females have chosen similarly the critical success factors of GBT.

\begin{tabular}{|c|c|c|c|c|c|c|c|c|}
\hline Gender & $\begin{array}{c}\text { Demand for } \\
\text { ubiquitous } \\
\text { (anywhere/an } \\
\text { ytime) } \\
\text { computing / } \\
\text { technology }\end{array}$ & $\begin{array}{c}\text { Cloud } \\
\text { computing } \\
\text { technology }\end{array}$ & $\begin{array}{c}\text { Lower costs } \\
\text { of Gesture } \\
\text { Based } \\
\text { Technology }\end{array}$ & $\begin{array}{c}\text { Accessibility } \\
\text { of Gesture } \\
\text { Based } \\
\text { Technology }\end{array}$ & $\begin{array}{c}\text { Size and } \\
\text { robustness } \\
\text { of Gesture } \\
\text { Based } \\
\text { Technology }\end{array}$ & $\begin{array}{c}\text { Having a } \\
\text { library of } \\
\text { gestures } \\
\text { (finger } \\
\text { taps, } \\
\text { finger } \\
\text { swipes, } \\
\text { etc) }\end{array}$ & $\begin{array}{c}\text { All of the } \\
\text { above }\end{array}$ & $\begin{array}{c}\text { None of } \\
\text { the } \\
\text { above }\end{array}$ \\
\hline Males & 27 & 19 & 21 & 21 & 16 & 4 & 10 & \\
\hline Females & 14 & 9 & 8 & 13 & 11 & 4 & 15 & 1 \\
\hline
\end{tabular}

\section{Table 9: Relationship between Gender and the Enablers of GBT}

Table 9 provides data on how male and female respondents chose enablers of GBT. Wijngaert and Bouwman (2009), Musuka (2006) state the importance of having demographic variables correlated with the enablers. Within the context of gender it would be to establish if any significant differences exist between males and females in relation to enablers chosen. It is generally accepted that males and females do have differing tastes, preferences and choices (Leedy \& Omrod 2005). As is evidenced in Table 17 males and females have chosen similarly the critical success factors of GBT.

\begin{tabular}{|c|c|c|c|c|c|c|c|c|}
\hline Gender & $\begin{array}{c}\text { Total cost of } \\
\text { ownership for } \\
\text { deploying } \\
\text { Gesture } \\
\text { Based } \\
\text { Technology } \\
\text { features of } \\
\text { Gesture } \\
\text { Based } \\
\text { Technology }\end{array}$ & $\begin{array}{c}\text { Limited } \\
\text { Gesture } \\
\text { Bechnology }\end{array}$ & $\begin{array}{c}\text { Stability of } \\
\text { scre and } \\
\text { ease of } \\
\text { use }\end{array}$ & $\begin{array}{c}\text { Gesture } \\
\text { Based } \\
\text { Technology } \\
\text { computers } \\
\text { capabilities } \\
\text { processor } \\
\text { power; } \\
\text { memory and } \\
\text { storage } \\
\text { capacity) }\end{array}$ & $\begin{array}{c}\text { Understanding a } \\
\text { multitude of } \\
\text { gestures at once }\end{array}$ & $\begin{array}{c}\text { All of the } \\
\text { above }\end{array}$ & $\begin{array}{c}\text { None of the } \\
\text { above }\end{array}$ \\
\hline Males & 34 & 11 & 9 & 12 & 12 & 10 & & \\
\hline Females & 18 & 8 & 9 & 6 & 13 & 7 & 7 & 3 \\
\hline
\end{tabular}

Table 10: Relationship between Gender and the Inhibitors of GBT 
As stated it is important to correlate the relationship between gender and three core sub problems that is critical success factors, enablers and inhibitors. In this section of the research study the relationship between gender and inhibitors is explored. The inhibitors like the critical success factors and enablers are extrapolated out of the literary review it is established that all six inhibitors presented to the sample have been selected. As evidenced in Table 10 there is a fairly even distribution between males and females in their choices of inhibitors.

\begin{tabular}{|c|c|c|c|c|c|c|c|}
\hline Gender & $\begin{array}{l}\text { The skills and } \\
\text { expertise of IT } \\
\text { in the } \\
\text { organisation }\end{array}$ & $\begin{array}{c}\text { The } \\
\text { Leaderships } \\
\text { view of } \\
\text { Gesture Based } \\
\text { Technology } \\
\text { within the } \\
\text { organisation }\end{array}$ & $\begin{array}{c}\text { Willingness } \\
\text { of users and } \\
\text { business to } \\
\text { adopt } \\
\text { Gesture } \\
\text { Based } \\
\text { Technology }\end{array}$ & $\begin{array}{c}\text { Cost of } \\
\text { Gesture } \\
\text { Based } \\
\text { Technology }\end{array}$ & $\begin{array}{c}\text { Having } \\
\text { Gesture } \\
\text { Based } \\
\text { Technology } \\
\text { being part of } \\
\text { the IT } \\
\text { strategy }\end{array}$ & $\begin{array}{c}\text { All of the } \\
\text { above }\end{array}$ & $\begin{array}{c}\text { None of the } \\
\text { above }\end{array}$ \\
\hline Males & 24 & 24 & 17 & 23 & 19 & 10 & 1 \\
\hline Females & 13 & 14 & 16 & 12 & 12 & 23 & 1 \\
\hline
\end{tabular}

\section{Table 11: Relationship between Gender and the Critical Success Factors of Strategy Alignment}

Table 11 provides data on how male and female respondents chose critical success factors of strategy alignment. The criticality of correlating gender to the critical success factors is to establish if any significant differences exist between the perceptions of males and females in relation to critical success factors (Wijngaert \& Bouwman 2009). As is evidenced in Table 11 both males and females have chosen similarly the critical success factors of strategy alignment.

As is evidenced by the analysis and table below, the enablers are the same across males and females. It is also evident that only two respondents, one male and one female selected that none of the enablers were relevant for strategy alignment. The enablers extrapolated from the research undertaken by Gregor, Hart, and Martin (2007) encompass: (1) Sharing business strategy with IT; (2) Having complementary IT and Organisational strategy; (3) Having and enterprise architecture for GBT; (4) Criticality of sharing information and 
knowledge across multiple platforms to the business; and (5) Lower costs of GBT. The sample selected all of the enablers presented to them.

\begin{tabular}{|c|c|c|c|c|c|c|c|}
\hline Gender & $\begin{array}{c}\text { Sharing the } \\
\text { business } \\
\text { strategy } \\
\text { with IT }\end{array}$ & $\begin{array}{c}\text { Having a } \\
\text { complimentary } \\
\text { IT and } \\
\text { Organisational } \\
\text { strategy }\end{array}$ & $\begin{array}{c}\text { Having an } \\
\text { Enterprise } \\
\text { Architecture } \\
\text { for Gesture } \\
\text { Based } \\
\text { Technology }\end{array}$ & $\begin{array}{c}\text { Criticality of } \\
\text { sharing } \\
\text { information } \\
\text { and } \\
\text { knowledge } \\
\text { across } \\
\text { multiple } \\
\text { plattorms } \\
\text { to the } \\
\text { business }\end{array}$ & $\begin{array}{c}\text { Lower costs } \\
\text { of Gesture } \\
\text { Based } \\
\text { Technology }\end{array}$ & $\begin{array}{c}\text { All of the } \\
\text { above }\end{array}$ & $\begin{array}{c}\text { None of the } \\
\text { above }\end{array}$ \\
\hline Males & 25 & 22 & 11 & 15 & 14 & 15 & 1 \\
\hline Females & 17 & 16 & 6 & 17 & 10 & 19 & 1 \\
\hline
\end{tabular}

Table 12: Relationship between Gender and the Enablers of Strategy Alignment

It is evident in the age groups twenty five to thirty four, thirty five to forty nine and fifty to sixty years are age groups with the greatest representation across the inhibitors. Once again all of the inhibitors extrapolated are applicable. It is also deduced that the respondents are predominantly within the ages of twenty five to fifty years. This once again confirms the diversity and wealth of knowledge available on new technologies. Wijngaert and Bouwman (2009) relate the importance of having a representative sample within the appropriate age bands.

The relationship between ranking in an organisation directly ties into the knowledge and understanding of any new technology and how this ties into the organisational strategy. Wijngaert and Bouwman (2009) succinctly encompass the criticality of ranking in relation to binding organisational strategy and any new technology. As stated, ranking is integral to gaining an accurate understanding and insight into the critical success factors, enablers and inhibitors.

Wijngaert and Bouwman (2009) state that ranking is crucial to understanding the data collected and can influence the outcomes of new technology on and organisation. The managerial ranking was representative followed by the non-managerial and administrative rankings. 
Gesture-based Technology and Organisational Strategy

\begin{tabular}{|c|c|c|c|c|c|c|c|c|}
\hline Ranking & $\begin{array}{c}\text { Having a } \\
\text { Wireless } \\
\text { Network in } \\
\text { place }\end{array}$ & $\begin{array}{l}\text { Accuracy in } \\
\text { capturing } \\
\text { gestures } \\
\text { (finger taps, } \\
\text { finger swipes } \\
\text { and finger } \\
\text { pointing) }\end{array}$ & \begin{tabular}{|c|} 
Accuracy in \\
interpreting \\
gestures \\
(finger taps, \\
finger swipes \\
and finger \\
pointing)
\end{tabular} & $\begin{array}{c}\text { Gesture } \\
\text { Based } \\
\text { Technology } \\
\text { ergonomics } \\
\text { and } \\
\text { durability }\end{array}$ & \begin{tabular}{|c|} 
Cost of \\
Gesture Based \\
Technology
\end{tabular} & \begin{tabular}{|c|} 
Various value \\
added \\
services \\
offered by the \\
Gesture \\
Based \\
Technology
\end{tabular} & $\begin{array}{c}\text { All of the } \\
\text { above }\end{array}$ & $\begin{array}{c}\text { None of } \\
\text { the above }\end{array}$ \\
\hline Managerial & 32 & 26 & 21 & 12 & 28 & 24 & 17 & \\
\hline $\begin{array}{c}\text { Non- } \\
\text { managerial }\end{array}$ & 7 & 7 & 7 & 6 & 8 & 9 & 11 & 1 \\
\hline Administrative & 2 & 2 & 2 & 2 & 2 & 2 & 4 & \\
\hline
\end{tabular}

Table 12: Relationship between Ranking and the Critical Success Factors of GBT

The effect of ranking on the inhibitors selected was minimal. Therefore there is a close correlation between the inhibitors for GBT chosen by the different ranks and those rendered. The conclusion is ranking did not affect the choice of inhibitors.

\begin{tabular}{|c|c|c|c|c|c|c|c|}
\hline Ranking & $\begin{array}{c}\text { The skills and } \\
\text { expertise of IT } \\
\text { in the } \\
\text { organisation }\end{array}$ & $\begin{array}{c}\text { The } \\
\text { Leaderships } \\
\text { view of } \\
\text { Gesture Based } \\
\text { Technology } \\
\text { within the } \\
\text { organisation }\end{array}$ & $\begin{array}{c}\text { Willingness } \\
\text { of users and } \\
\text { business to } \\
\text { adopt } \\
\text { Gesture } \\
\text { Based } \\
\text { Technology }\end{array}$ & $\begin{array}{c}\text { Cost of } \\
\text { Gesture } \\
\text { Based } \\
\text { Technology }\end{array}$ & $\begin{array}{c}\text { Having } \\
\text { Gesture } \\
\text { Based } \\
\text { Technology } \\
\text { being part of } \\
\text { the IT } \\
\text { strategy }\end{array}$ & $\begin{array}{c}\text { All of the } \\
\text { above }\end{array}$ & $\begin{array}{c}\text { None of } \\
\text { the above }\end{array}$ \\
\hline Non- & 10 & 10 & 10 & 8 & 27 & 20 & 1 \\
managerial & 26 & 28 & 22 & 0 & 1 & 3 & 10 \\
\hline Administrative & 1 & & 1 & & & \\
\hline
\end{tabular}

Table 13: Relationship between Ranking and the Critical Success Factors of Strategy Alignment 
To iterate Wijngaert and Bouwman (2009), ranking is key to understanding the data collected, and can influence the outcomes of technology and strategy alignment. Table 13 summarises the findings of the critical success factors for strategy alignment across the various rankings. The managerial ranking again dominates the findings. As expected the administrative ranking is the least representative. Two respondents (one managerial and one non-managerial) state that none of critical success factors are applicable.

\begin{tabular}{|c|c|c|c|c|c|c|c|}
\hline Ranking & $\begin{array}{c}\text { Sharing } \\
\text { the } \\
\text { business } \\
\text { strategy } \\
\text { with IT }\end{array}$ & $\begin{array}{c}\text { Having a } \\
\text { complimentary } \\
\text { IT and } \\
\text { Organisational } \\
\text { strategy }\end{array}$ & $\begin{array}{c}\text { Having an } \\
\text { Enterprise } \\
\text { Architecture } \\
\text { for Gesture } \\
\text { Based } \\
\text { Technology }\end{array}$ & $\begin{array}{c}\text { Criticality of } \\
\text { sharing } \\
\text { information } \\
\text { and } \\
\text { knowledge } \\
\text { across } \\
\text { multiple } \\
\text { platforms to } \\
\text { the business }\end{array}$ & $\begin{array}{c}\text { Lower costs } \\
\text { of Gesture } \\
\text { Based } \\
\text { Technology }\end{array}$ & $\begin{array}{c}\text { All of the } \\
\text { above }\end{array}$ & $\begin{array}{c}\text { None of } \\
\text { the } \\
\text { above }\end{array}$ \\
\hline Managerial & 29 & 30 & 13 & 21 & 17 & 24 & \\
\hline $\begin{array}{c}\text { Non- } \\
\text { managerial }\end{array}$ & 11 & 7 & 4 & 8 & 5 & 8 & 2 \\
\hline Administrative & 2 & 1 & & 3 & 2 & 2 & \\
\hline
\end{tabular}

\section{Table 14: Relationship between Ranking and the Enablers of Strategy Alignment}

Table 14 summarises the findings for the enablers of strategy alignment across the various rankings. The managerial ranking dominated the responses. The correlation of the enablers for strategy alignment and ranking were similar. Therefore, ranking had little effect on the respondents' selections of enablers as extrapolated by the research of Chen (2010), Huang and $\mathrm{Hu}$ (2007), and Tallon (2008).

These inhibitors are hinged on the research undertaken by Chan and Reich (2007), Chen (2010), and Huang and $\mathrm{Hu}$ (2007). All the inhibitors have been selected by the respondents. From the analysis above the managerial ranking dominates the findings. However overall there is no difference between the different rankings with respect to the inhibitors for strategy alignment selected. Therefore ranking does not influence the inhibitors of strategy alignment. 


\section{Findings and Recommendations}

Wijngaert and Bouwman (2009) note that it is critical to have a sample that is diverse in its representation of age and gender composition. Having such representation will enable insightful and knowledge contributing views to be derived. The majority of respondents of the sample fall in the age group of between twenty five and thirty four (25-34) year. Implicit in this finding is that there will be a diversity of perceptions and knowledge of GBT with respect to organisational strategy. This also signals there will be varied and extremely insightful views on the aims and objectives of the research.

\section{Knowledge of Gesture Based Technology (Gbt)}

Johnson et al. (2010), Lee (2010) state that it is important to have knowledge of any new technology in order to effectively use it and understand its use and benefits. Wijngaert and Bouwman (2009) reiterate this view by stating that the readiness of acceptance and knowledge of the technology lead to successful adoption and use of technology. The respondents knowledge of GBT fell within a normal distribution and the majority of the sample had either expert or novice knowledge. From this analysis it is evident that the knowledge of GBT is not significant and more importantly cannot adequately support any of the research findings objectives.

The critical success factors presented to the sample were extrapolated from the literature researched. These critical success factors focused distinctly on GBT and strategy alignment. The key finding is that a wireless network and cost of GBT is the heart and soul of the critical success factors. These two findings are in line with the research undertaken by Gegor et al. (2007). The top three inhibitors indentified by the sample include: the total cost of ownership for deploying GBT; GBT capabilities (process power; memory and storage capacity); and limited features of GBT. These findings are indifferent to Roussos and Kostakos (2009). The cost of GBT can be considered the most important criteria for the alignment of GBT and organisational strategy. It has featured as critical success factor, an enabler and now an inhibitor. Therefore ensuring the correct pricing of this technology will lead to mass adoption and arguably alignment of organisational strategy and GBT (Gegor, Hart and martin 2007).

The critical success factors presented to the sample for the alignment of GBT and organisational strategy were extrapolated from the literature 
presented by Chan and Reich (2007), Tarafdar and Qrunfleh (2009), Chen (2010), Huang and $\mathrm{Hu}$ (2007). There is not deviation to the literature that was found. The findings reaffirmed the critical success factors that were presented to the sample. An explanation of the findings is detailed below.

\section{Enablers}

Sharing the business strategy with IT featured as the number one enabler for strategy alignment. This shows the importance of having the IT department knowing what the business intends on doing, which will enable it to support the organisation. Chan and Reich (2007), and Chen (2010) argue the same in their literature. The second ranked enabler for strategy alignment was having a complimentary IT and organisational strategy. This enabler was extracted from the research undertaken by Huang and $\mathrm{Hu}$ (2007).

\section{Relationship Testing}

A key component of the research paper is testing the relationships between various variables. Wijngaert and Bouwman (2009) and Musuka (2006) all advise that having a representative sample ill result in insightful and incisive research.

\section{Research Questions}

In this section the research question is answered. A recollection of the research problem is: What are the Critical Success Factors (CSF's), Enablers and Inhibitors that would drive that alignment of GBT (touch screen, smart phone and tablet technology) and organisational strategy to ensure competitive advantage and enhanced business performance.

Sub-Question 1: What are critical success factors for the alignment of gesture based technology (touch screen, smart phone and tablet technology) and organisational strategy?

From the data gathered it is evident that six critical success factors have been presented for consideration, for GBT. These critical success factors were extrapolated from the research undertaken by Chan and Reich (2009). The 
focus of this analysis would be to assess if there are significant deviations from or with the proposed critical success factors that are hinged on the literature.

The seventh critical success factor states that all of the critical success factors are important whilst the eight option states that none of the options presented are important or relevant. Therefore the combined weighting of the six options presented add up to $85.8 \%$. This weighting is significantly higher than the 50th percentile and above the median. This shows that the findings are aligned with the literature reviewed and confirm that these critical success factors are indeed appropriate and relevant.

Similarly, seven options have been presented to the sample as choices for the critical success factors for strategy alignment. Five of these options were extrapolated from the research undertaken by Chan and Reich (2007), Tarafdar and Qrunfleh (2009), and Huang and Hu (2007). The five options add up to a weighting of $83.2 \%$. The 'all of the above' option has a percentage of $15.8 \%$. Once again all of the options presented are significantly above the median, whilst the 'none of the above' is significantly below the median. The implicit pronouncement is that the literature and the findings are aligned and the findings can be adopted.

Therefore all critical success factors are recommended. Due to the cost option being included in both GBT and strategy alignment and chosen, it is only stated once, therefore reducing the critical success factors recommenddation to ten options. These are as follows:

1. Having a Wireless Network in place;

2. Accuracy in capturing gestures (finger taps, finger swipes and finger pointing);

3. Accuracy in interpreting gestures (finger taps, finger swipes and finger pointing);

4. GBT ergonomics and durability; and

5. Cost of GBT.

\section{Sub-Question 2: What are the enablers for the alignment of} gesture based technology (touch screen, smart phone and tablet technology) and organisational strategy?

When the data is analysed for the enablers of GBT and strategy alignment the same conclusions can be drawn as per the critical success factors stated above. 
The combined weighting of the six options for enablers of the GBT is equal to $86.4 \%$, whilst the combined weighting for five options of strategy alignment is equal to $80.9 \%$. With the enablers of strategy alignment what is evident that any two options together with 'the all of the above option' will have a weighting greater than $50 \%$.

Therefore ten enablers are presented as enablers for the alignment of GBT and organisational strategy alignment. Once again lower costs are presented as an option in both GBT and strategy alignment, and chosen in both instances. Therefore it is rendered only once below as it is applicable to both areas. Some of the enablers are as follows:

1. Demand for ubiquitous (anywhere/anytime) computing / technology;

2. Cloud computing technology;

3. Lower costs of GBT;

4. Accessibility of GBT; and

5. Size and robustness of GBT.

Sub-Question 3: What are the inhibitors to the alignment of gesture based technology (touch screen, smart phone and tablet technology) and organisational strategy

The inhibitors recommended for this research sub-problem encompasses the eleven options (six for GBT and five for strategy alignment) presented to the sample. Both the six options presented for GBT and the five options presented for strategy alignment have a weighting of above 50\% and are above the median. The 'none of the above' options presented in each instance have a weighting of $1.8 \%$ and $1.2 \%$ respectively. These are significantly below the median and can easily be rejected. Some of the recommended inhibitors are therefore as follows:

1. Total cost of ownership for deploying GBT

2. GBT computers capabilities (processor; power; memory and storage capacity)

3. Limited features of GBT

4. Stability of GBT

5. Screen size and ease of use 
The above inhibitors are indifferent to the inhibitors presented by Wijngaert and Bouwman (2009), Roussos and Kostakos (2009). This confirms the reliability of the findings. The aim of the analysis was to solve for the critical success factors, enablers and inhibitors that could be used to formulate a theoretical framework for the alignment of GBT and organisational strategy. Crucial to this analysis and research paper was the need to distil established and existent critical success factors, enablers and inhibitors to the sample for review and selection. The expectation was that there would be very little, or no deviation from the extrapolated critical success factors, enablers and inhibitors presented.

\section{Recommendations}

Chen (2010) advises that having a concise and accurate focus is the foundation for a successful strategy. Therefore the theoretical framework recommenddations took in to consideration the top three findings for each of the sub problems focus areas, that is GBT and strategy alignment. These top three findings for each focus area where chosen based on its ranking. Implicit in this is that the top three were chosen on a rating of ascending order. The synergies and critical overlaps of the top three findings single them out as the heart and soul of the recommendations. However, this does not prohibit the various other findings to be used as part of the theoretical framework and can appropriately be adapted. The critical success factors for the theoretical framework recommendations are:

1. The organisation must have a wireless network in place;

2. The cost of GBT must be in line with the organisation's expectations;

3. GBT must accurately capture gestures (finger taps, finger swipes and finger pointing).

The recommendations for the enablers of the theoretical framework encompass:

1. Having an organisation that is demanding of ubiquitous (anywhere/ anytime) computing or technology;

2. Having accessibility to GBT; and 


\section{Decreasing costs of GBT.}

The inhibitors for the theoretical framework include:

1. Total cost of ownership for deploying GBT within the organisation;

2. The hardware capabilities (processor power; memory and storage capacity) of GBT devices; and

3. GBT having limited features.

The first recommendation is the need to drive communication across all tiers of the organisation around technology evolution and organisational strategy. Some respondents signalled a lack of understanding of GBT and the organisational strategy, which sparked the communication need. The second recommendation entails ensuring that all ranks within the organisation are included in the strategy formulation process. This would include the technology strategy formulation as well. The next recommendation entails driving greater training initiatives that would enable sharing technology knowledge, organisational knowledge and associated information within the organisation. Finally, any new technology deployment requires significant monetary investment. By including the costs associated to new technology in the planning process (three or five year cycle) the organisation can adequately budget in the costs of new technology.

\section{Conclusion}

The newness of GBT lends itself to research and from the literature review it is evident that there is a dire need to have GBT and organisational strategy aligned. The focus of this is the discussion around the research analysis and the provision of recommendations for the research study. This is initiated with an introduction and flows into the discussion of the analysis of the previous. It is followed by recommendations. The recommendations entail the theoretical framework recommendations, general recommendations and recommenddations for research.

The heart of recommendations is the critical success factors, enablers and inhibitors for the theoretical framework. Six critical success factors have been recommended for the theoretical framework. The key critical success factor identified is having a wireless network in place. Seven enablers are recommended and the key enabler was the demand to ubiquitous computing 
and technology. Finally, six recommendations have been made for the inhibitors and the number one recommendation is the cost of deploying GBT. It is interesting that the cost of GBT spanned across the critical success factors, enablers and inhibitors. Therefore cost can be considered the most important recommendation for the theoretical framework.

It is also recommended that organisations drive communication across all tiers of its organisation to ensure knowledge and information sharing of technology and organisational strategy. A key future research recommendation entails creating a criticality matrix for the critical success factors, enablers and inhibitors of GBT and strategy alignment. The section is finally concluded and ultimately results in the conclusion of the research study.

\section{References}

Blanchard, K., J. Ballard \& F. Finch 2004. Customer Mania. New York, NY: Free Press, Blanchard Family Partnership.

Bush, M., A.L. Lederer, X. Li, J. Palmisanno \& S. Rao 2009. The Alignment of Information Systems with Organisational Objectives and Strategies in Health Care. International Journal of Medical Informatics 78: 446 - 456. https://doi.org/10.1016/j.ijmedinf.2009.02.004

Chang, H. \& C. Yang 2008. Do Airline Self-service Check-in Kiosks Meet the Needs of Passengers? Tourism Management 29: 980 - 993.

https://doi.org/10.1016/j.tourman.2007.12.002

Chan, E.Y. \& B.H. Reich 2007. IT Alignment: What have we Learned? Journal of Information Technology 22: 297 - 315.

https://doi.org/10.1057/palgrave.jit.2000109

Cheng, Y. \& S.H. Wang SH 2010. Applying a 3D Virtual Learning Environment to Facilitate Student's Application Ability - The Case of Marketing. Computers in Human Behavior 27: 576 - 584.

Chen, L. 2010. Business-IT Alignment Maturity of Companies in China. Information and Management 47: 9 - 16.

https://doi.org/10.1016/j.im.2009.09.003

Gregor, S., D. Hart \& N. Martin 2007. Enterprise Architectures: Enablers of Business Strategy and IS/IT Alignment in Government. Information Technology and People 20,2: 96 - 120.

https://doi.org/10.1108/09593840710758031 
Huang, C.D. \& Q. Hu 2007. Achieving IT-Business Strategic Alignment via Enterprise-Wide Implementation of Balanced Scorecard. Information Systems Management 24: 173 - 184.

https://doi.org/10.1080/10580530701239314

Johnson, L., A. Levine, R. Smith \& S. Stone 2010. The 2010 Horizon Report. Austin, Texas: The New Media Consortium.

Lee, T.W. 2010. Using Qualitative Methods in Organizational Research. Thousand Oaks, California: Sage Publications, Inc,

Leedy, P.D. \& J.E. Omrod 2005. Practical Research - Planning and Design. $8^{\text {th }}$ Edition. Upper Saddle River, New Jersey: Pearson, Merrill Prentice Hall. Lubbe, S. 2005. Strategic Alignment of Organisational Strategies. Encyclopedia of Information Science and Technology 5:2622 - 2626.

Lubbe, S. \& S. Pather 2003. Key Indicators for Successful Internet Commerce:

A South African Study. The Economic and Social Impacts of $e$ Commerce. Hershey PA, USA: Idea Group Inc.

https://doi.org/10.4018/978-1-59140-043-1.ch009

Mistry, P., P. Maes \& L. Chang 2009. WUW - Wear Ur World: A Wearable Gestural Interface. Proceedings of the $27^{\text {th }}$ International Conference Extended Abstracts on Human Factors in Computing Systems, April 0409, 2009, Boston, MA, USA.

https://doi.org/10.1145/1520340.1520626

Musuka, P. 2006. Alignment of IT Strategy with Business Strategy: Impact on IT Effectiveness and Business Performance. Graduate School of Business Leadership. University of South Africa.

Nijholt, A., D. Plass-Oude \& B. Reuderink 2009. Turning Shortcomings into Challenges: Brain-computer Interfaces for Games. Entertainment Computing 1: 85 - 94. https://doi.org/10.1016/j.entcom.2009.09.007

Roth, W.M. 2000. From Gesture to Scientific Language. Journal of Pragmatics 32: 1683 - 1714.

https://doi.org/10.1016/S0378-2166(99)00115-0

Roussos, G. \& V. Kostakos 2009. RFID in Pervasive Computing: State-of-theart and Outlook. Pervasive and Mobile Computing 5: 110 - 131. https://doi.org/10.1016/j.pmcj.2008.11.004

Shah, N. \& C. Haigh 2005. The Video Game Industry - An Industry Analysis, from a VC Perspective. Hanover, NH: Glassmeyer/ McNamee Centre for Digital Strategies. 
Tallon, P.P. 2008. A Process-Oriented Perspective on the Alignment of Information Technology and Business Strategy. Journal of Management Information Systems 24, 3: 227 - 268.

https://doi.org/10.2753/MIS0742-1222240308

Tarafdar, M. \& S. Qrunfleh 2009. Examining Tactical Information Technology - Business Alignment. Journal of Computer Information Systems 107116.

Wilson, A.D. 2004. TouchLight: An Imaging Touch Screen and Display for Gesture Based Interaction. Pennsylvania, USA: ICMI 04, State College, Wijngaert, L.V.D. \& H. Bouwman 2009. Would you Share? Predicting the Potential Use of a New Technology. Telematics and Informatics 26: 82 102.

https://doi.org/10.1016/j.tele.2008.01.002

Wobbrock, J.O., B.A. Myers \& H.H. Aung 2008. The Performance of Hand Postures in Front- and Back-of-device Interaction for Mobile Computing. International Journal of Human - Computer Studies 66: 857 - 875. https://doi.org/10.1016/j.ijhcs.2008.03.004

Wu, F.G. \& S. Luo 2006. Performance Study on Touch-pens Size in Three Screen Tasks. Applied Ergonomics 37: 149 - 158.

https://doi.org/10.1016/j.apergo.2005.08.005 https://doi.org/10.1016/j.apergo.2005.05.011

Nishal Ragobeer School of Business Leadership University of South Africa nragobeer@gmail.com

Rembrandt Klopper Department of Communication Science Faculty of Arts University of Zululand, South Africa rklopper@gmail.com

Sam Lubbe Milpark Business School Milpark Education South Africa sam.lubbe@gmail.com 